\title{
Customary Forest Managements and Its Challenges in East Nusa Tenggara, Indonesia: An Implication of Constitutional Court Decision 2012
}

\author{
Imam Budiman ${ }^{1}$, Takahiro Fujiwara ${ }^{2 *}$ Kazuhiko Harada ${ }^{3}$, Noriko Sato ${ }^{2}$ \\ ${ }^{1}$ Graduate School of Bioresource and Bioenvironmental Sciences, Kyushu University, 744 Motooka Nishiku Fukuoka, \\ Japan 819-0395 \\ ${ }^{2}$ Faculty of Agriculture, Kyushu University, 744 Motooka Nishiku Fukuoka, Japan 819-0395 \\ ${ }^{3}$ Graduate School of Bioagricultural Sciences, Nagoya University, Furocho, Chikusa Aichi, Japan 464-8601
}

Received July 30, 2020/Accepted May 4, 2021

\begin{abstract}
Customary forests have not been adequately recognized in state forest management in Indonesia for a long time. However, in the last decades, several fundamental policy changes occurred, and the roles of local communities significantly recognized in forest management. The forest tenure reforms for customary communities are actively addressed after the Constitutional Court Decision (CCD) Number 35 in 2012. The objectives of this study are (1) to determine the changes in customary forest management in response to the CCD and (2) to discuss policy challenges after the CCD in East Nusa Tenggara Province. This study employed qualitative descriptive analysis methods. The result showed the different responses of customary communities related to the institutional development towards $C C D$. The lack of local regulations regarding customary peoples' rights still need to be solved. Besides, the claims of customary communities for customary forests overlapping with state conservation areas and other customary forests can make the problem more complicated.
\end{abstract}

Keywords: customary forest, East Nusa Tenggara, CCD Number 35/2012

*Correspondenceauthor:takaf217@agr.kyushu-u.ac.jp

\section{Introduction}

Background Customary forests have not been adequately recognized in state forest management in Indonesia for a long time. The Agrarian Law of 1870 (Agrarische Wet) and the Forestry Special Act of 1927 (Boschordonnantie) eroded land rights of indigenous people and customary communities in Indonesia (Asmin, 2016; Bedner \& Arizona, 2019). They also systematically and structurally marginalized the roles of indigenous people and customary communities in forest management. The domain statement (Domeinverklaring) in the Agrarian Law 1870 only recognized private lands with certificates and ignored customary lands based on customary rights. Van Vollenhoven, a Dutch Scholar in the colonial era, divided Indonesia into 19 customary law areas across the archipelago; however, such customary communities were incorporated into an integral part of the socioeconomic system of Indonesia. Indonesia's Constitution states that there are at least 250 areas under the sultanates, kingdoms, and customary people in Indonesia (Sirait et al., 2000).

After Indonesia's independence in 1945, two laws of the colonial era were replaced with new ones: the Basic Agrarian Law of 1960 (hereafter, the BAL) and the Basic Forestry Law of 1967. The BAL has acknowledged the existence of indigenous and tribal peoples (Krishna, 2017). Soemardjan (1962) pointed three essential features of the BAL: 1) accordance with the interests of the Indonesian people, especially farmers, 2) simplification of the dualism of the agrarian system related to the customary law of indigenous peoples, and 3) provision of legal guarantee for people with agrarian rights. When the government started implementing BAL, there were two land systems in Indonesia: a traditional hereditary system and a market system through the titling or certification (Suartika, 2007). Even though BAL abolished the Agrarian Law of 1870 , it substantially recreated the different domain statements. In other words, the BAL gave the government power to regulate, handle, and determine the land and natural resources of Indonesia (Siscawati et al., 2017).

Equal opportunities for forest management were not brought adequately to indigenous people and customary communities during developmentalism by President Suharto's New Order regime (1966-1998). In the name of "development" or "national interest," they muted local conflicts through coercive approaches for giving land management rights to private companies. Hidayat et al. (2018) mention that two relevant policies made indigenous people marginalized in the New Order regime: concession system and transmigration program. The concession system was purposed to improve the income from the forestry and mining industry. Meanwhile, the transmigration program was introduced to overcome the population explosion problem in Java island. In other words, both policies created vast demands for extensive lands. 
Fundamental policy changes occurred in the Reformation era after the end of the New Order regime. The roles of local communities in forest management have been gradually recognized. Non-governmental Organizations (hereafter, NGOs) have been active in struggling for the indigenous people and customary communities to return their customary property rights held by the state. One of them is the Indonesian Indigenous People Alliance (Aliansi Masyarakat Adat Nusantara, hereafter AMAN). They have raised the slogan: if the state does not recognize indigenous peoples, then indigenous peoples also do not need to recognize the state (Guest, 2017). The revival of the indigenous people's movements is triggered by not only anti-colonial movements but also changes in international intellectual life (Hidayat et al., 2018). In tandem with those movements in Indonesia, at the international level, the United Nations General Assembly adopted the United Nations Declaration on the Rights of Indigenous People (UNDRIP) on September 13, 2007. It was one of the critical turning points to raise awareness of indigenous peoples' rights globally (Almeida, 2014). The UNDRIP shows five fundamental rights of indigenous peoples: 1) right of self-determination, 2) right of property, 3) right of culture, 4) right of health, education, and work, 5) right of free informed prior consent (Jampolsky \& Carpenter 2015).

Eventually, Constitutional Court Decision Number 35 (hereafter, CCD) was enacted in 2012. The forest tenure reforms for customary communities have been more active after the CCD enactment. Before the CCD, there were only two statuses of forests in Indonesia based on the Forestry Law of 1999: state forest (hutan negara) and right forest (hutan hak). At that time, the forestry laws defined customary forests (hutan adat) as "state forests" within an area of customary law communities. However, the CCD declared that customary forests were forests within an area of customary law communities, and it removed the word of the "state (negara)" from the forestry law. Consequently, the customary forests won the independent statuses that are neither state forests nor rights forests in the forest management of Indonesia.

Research aim Customary communities have strong interactions with forests and have local wisdom of protecting forests and the environment (Roth, 2011; Camacho et al., 2012). They also have their own identity distinguishing them from others (Bakker \& Moniaga, 2010). The CCD has been bringing new hope for the customary communities (Subarudi, 2014). To realize the CCD principles, Suryadi (2013) urged the importance of the new regulations that explain more details about customary forest management, including the rights and obligations of the customary community. The Ministerial Regulation Number 17/2020 about the Customary Forest and Right Forest also prescribes that regional regulations must expressly stipulate the customary law community's regulations. In recent years, regions that have regional regulations on customary communities increased significantly. The MoEF shows that at least 52 regional governments enacted the regulations until mid-2019 (Ditjen PSKL KLHK, 2019), however, not all regions have had the regulations yet.

There are many previous studies on customary communities and customary forests in Indonesia. Most previous studies employed historical approaches and provided some conception of customary communities and forests (e.g. Peluso \& Vandergeest, 2001; Vandergeest \& Peluso, 1995; 2015). Some of them also helped develop customary forests at the national level (e.g. Peluso et al., 2008; Subarudi, 2014). Those studies mainly focused on cases of a big and well-known area in Indonesia, such as Java (e.g. Lund \& Rachman, 2018), Sumatera (e.g. Powell et al., 2000), and Sulawesi (e.g. Wibowo et al., 2014). In contrast, only few studies focused on forest management in fragmented land regions, such as East Nusa Tenggara Province (hereafter ENT Province). Kilkoda (2015) reported that improper forest management in small islands negatively impacted the forest and environmental ecosystems and brought problems to human living space. On the other hand, Iswandono et al. (2016) mentioned that various ethnic groups with unique livelihoods sustainably managed many natural resources in small islands. Indonesia is an archipelago country composed of countless tiny islands. Therefore, further studies focusing on small islands are necessary to discuss customary forests and their policymaking in Indonesia.

The ENT Province is one of the outermost and fragmented areas in Indonesia. It is one of the provinces which has many local customs and small customary communities. The Customary Region Registration Body (Badan Registrasi Wilayah Adat, hereafter BRWA) has registered 32 customary communities of the ENT Province. However, the ENT Provincial Government has not acknowledged any customary communities and forests. Therefore, the CCD has not yet been well-implemented in ENT Province. It appears there are some barriers to develop customary forests in ENT Province. The objectives of this study are to (1) to determine the changes in customary forest management and (2) discuss the policy challenges after the CCD in the ENT Province.

\section{Methods}

Study site The ENT Province (Figure 1) is composed of many small islands. It is also well-known as the location where the languages, cultures, people, flora, and fauna meet each other (Grimes et al., 1997) There are 55 ethnic groups in the province, corresponding to about $10 \%$ of the total number of ethnic groups in Indonesia (Upton, 2017). They formed some small kingdoms in the past and firmly maintained the customary system for land ownership and distribution (Monk et al., 1997). The ENT Province has no concessions and another land utilization hindering building recognition of customary forests (Myers et al., 2017). Therefore, the contestation commonly comes between conservation areas (Iswandono et al., 2015; Kriswoyo et al., 2019) or between other family clans (Sopian, 2015).

Among the ethnic groups in the ENT Province, we selected (1) Baranusa customary community in the Alor District of Pantar Island, (2) Mollo customary community in the Timor Tengah Selatan District of Timor Island, and (3) Nua Wologai customary community in the Ende District of Flores Island for data collection as the following reasons (Table 1). The Baranusa customary community registered the most expansive customary area (around 5.000 ha) to BRWA since 2 June 2017. However, the regional government 


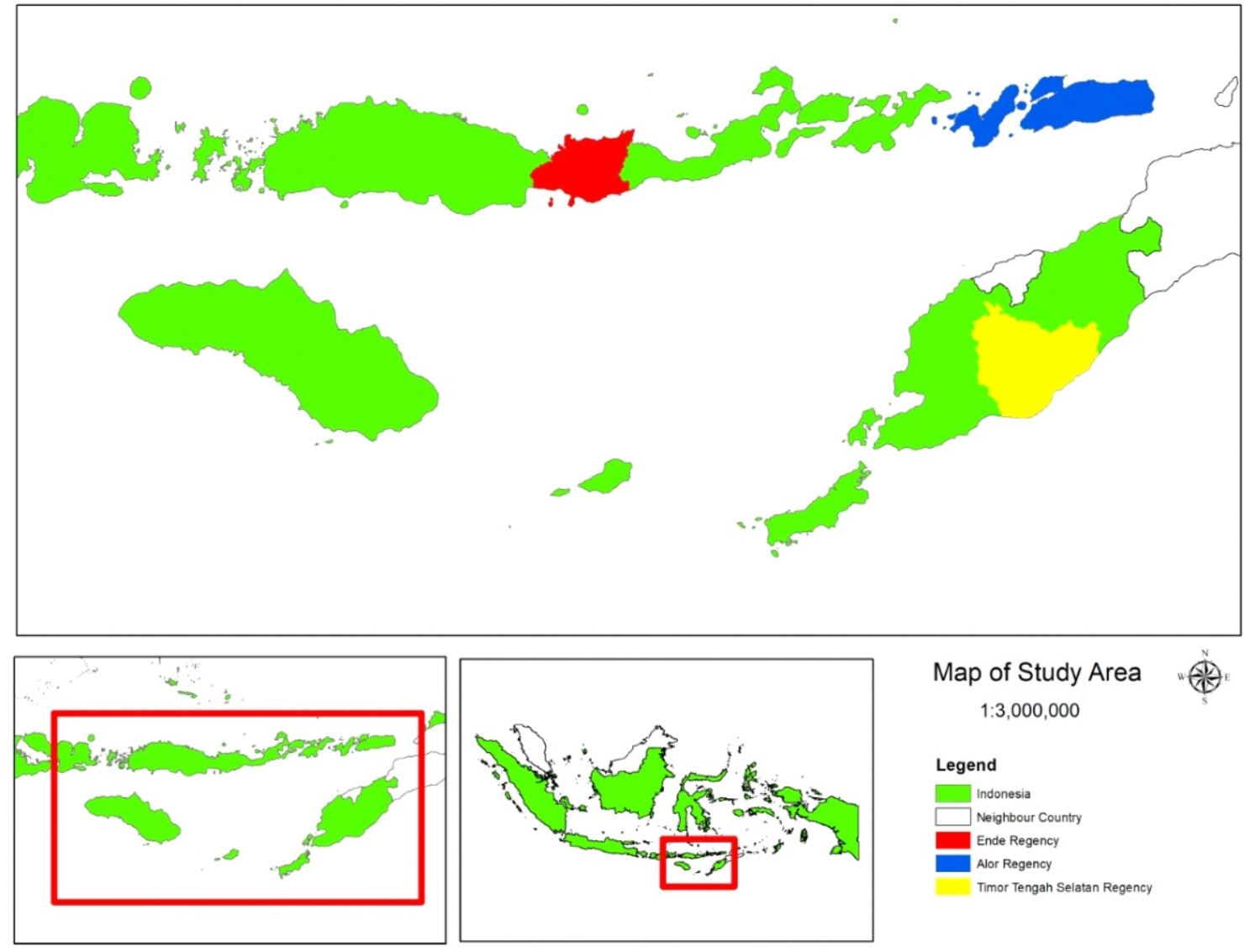

Figure 1 Research site location (Map source: Indonesian Geospatial Information Agency, 2018).

has not yet acknowledged their customary area until today. The Mollo customary community is one of the biggest ethnic groups in Timor Island, but they have never registered their customary forests neither to BRWA nor to the government agency. The Nua Wologai customary community is located in the Ende District, where the regional government enacted regional regulation on customary community early after the CCD; however, they have not yet gotten legal recognition until today. All three customary communities are the heirs of those kingdoms or tribes and have kept a clear lineage and customary norms until today. They also have close interactions with nature, including forests. Therefore, we expected that comparing three customary communities with different conditions of their customary forests would provide useful material to discuss policy challenges of the CCD.

Data collection We conducted in-depth interviews with key informants on February-March 2018, March-April 2019, and November 2019. The key informants are (1) officers of central government agencies represented by the MoEF, (2) officers of local government agencies, (3) staffs of NGOs focusing on customary communities' rights problems, and (4) representatives of customary communities. The interview items included 1) the progress of customary forests' developments, 2) the process of advocating, mapping, and registration of customary forests, and 3) actual conditions of customary communities on managing their customary forests. We collected secondary data in parallel with the interviews (i.e., statistical data and related documents).

This research elaborates the qualitative study, which conducting observation, interview, and documentation during data collection (Creswell \& Creswell, 2018). We also employed descriptive policy analysis, which described concerns with evaluating a new policy as it is implemented. The policy analysis is conducted after policy implementation, and the primary concern is to understand the problem rather than solve it (Dunn, 1981). We further discuss the results using the Legal Recognition Process Scheme framework formulated by Arizona et al. (2019). This framework figures out the process of legal recognition, which consisted of some steps from initiating the customary forests issue until its recognition/pra-recognition. We also expand our discussion based on these steps: 1) land tenure problem analysis, 2) preparation on entering the legal process, 3 ) legal recognition process, 4) post legal recognition (Figure 2).

\section{Results and Discussion}

Table 2 shows the forest and land management of the three customary communities and their response towards the CCD. 
Table 1 The characteristics of the three customary communities

\begin{tabular}{|c|c|c|c|}
\hline Parameter & $\begin{array}{c}\text { Mollo } \\
\text { (TTS District) }\end{array}$ & $\begin{array}{c}\text { Baranusa } \\
\text { (Alor District) }\end{array}$ & $\begin{array}{r}\text { Nua Wologai } \\
\text { (Ende District) }\end{array}$ \\
\hline General characteristic & $\begin{array}{l}\text { The largest ethnic group } \\
\text { in Timor Island }\end{array}$ & $\begin{array}{l}\text { The largest tribes in the } \\
\text { Pantar Island }\end{array}$ & $\begin{array}{l}\text { One of the small tribes } \\
\text { Florest Island }\end{array}$ \\
\hline History/genealogy & $\begin{array}{l}\text { The descents of previous } \\
\text { Oenam people, } \\
\text { transformed into several } \\
\text { sub-districts }\end{array}$ & $\begin{array}{l}\text { The descents of the } \\
\text { previous Baranusa } \\
\text { kingdom, transformed } \\
\text { into one village }\end{array}$ & $\begin{array}{l}\text { The descents of previous } \\
\text { small tribes kingdom } \\
\text { Nua Wologai, } \\
\text { transformed into one } \\
\text { village }\end{array}$ \\
\hline $\begin{array}{l}\text { Main cultural activity } \\
\text { (natural resources } \\
\text { utilization) }\end{array}$ & $\begin{array}{l}\text { NTFPs gathering, } \\
\text { traditional land tenurial } \\
\text { system, wedding } \\
\text { ceremony }\end{array}$ & $\begin{array}{l}\text { Marine products } \\
\text { gathering }\end{array}$ & $\begin{array}{l}\text { Ritual activity, } \\
\text { traditional land tenurial } \\
\text { system }\end{array}$ \\
\hline $\begin{array}{l}\text { Claimed/proposed } \\
\text { customary } \\
\text { community/area }\end{array}$ & $\begin{array}{l}\text { Access to the } \\
\text { conservation } \\
\text { forest/protected forest }\end{array}$ & $\begin{array}{l}\text { Limitation of collection } \\
\text { of marine products in } \\
\text { some periods }\end{array}$ & $\begin{array}{l}\text { Access to the protected } \\
\text { forest }\end{array}$ \\
\hline Dominant norm & $\begin{array}{l}\text { The triangle system of } \\
\text { life (harmony between } \\
\text { human, livestock, and } \\
\text { forest) }\end{array}$ & $\begin{array}{l}\text { Hading Mulung \& Hoba } \\
\text { Mulung ("grace periods" } \\
\text { of sea products } \\
\text { harvesting) }\end{array}$ & $\begin{array}{l}\text { Tiga Batu Tungku (the } \\
\text { harmony between } \\
\text { stakeholder to manage } \\
\text { the forest) }\end{array}$ \\
\hline $\begin{array}{l}\text { Possibilities for } \\
\text { customary } \\
\text { forest/customary } \\
\text { community } \\
\text { acknowledgment }\end{array}$ & $\begin{array}{l}\text { Customary forest } \\
\text { coexisted with state } \\
\text { forest }\end{array}$ & $\begin{array}{l}\text { Customary community } \\
\text { area }\end{array}$ & Customary forest \\
\hline $\begin{array}{l}\text { Important motives for } \\
\text { recognition }\end{array}$ & $\begin{array}{l}\text { Secure access for daily } \\
\text { livelihood }\end{array}$ & $\begin{array}{l}\text { Conserve the coastal } \\
\text { reef for the sustainability } \\
\text { of sea products }\end{array}$ & $\begin{array}{l}\text { Forest for religious and } \\
\text { cultural activity }\end{array}$ \\
\hline Main NGO connection & WWF Nusa Tenggara & $\begin{array}{l}\text { AMAN Indonesia } \\
\text { WWF Lesser Sunda } \\
\text { Projects }\end{array}$ & AMAN Nusa Bunga \\
\hline $\begin{array}{l}\text { Presence of district } \\
\text { regulation related to the } \\
\text { customary community }\end{array}$ & No district regulation & $\begin{array}{l}\text { District regulation } \\
\text { Number } 4 / 2018 \text { about } \\
\text { Recognition and } \\
\text { empowerment of } \\
\text { customary institutions }\end{array}$ & $\begin{array}{l}\text { District regulation } \\
\text { Number } 2 / 2017 \text { about } \\
\text { Implementation of } \\
\text { recognition and } \\
\text { protection of customary } \\
\text { law communities in } \\
\text { Ende District }\end{array}$ \\
\hline
\end{tabular}

\begin{tabular}{|l|l|c|c|c|}
\hline & $\begin{array}{c}\text { Land tenure } \\
\text { analysis }\end{array}$ & $\begin{array}{c}\text { Preparation on } \\
\text { entering legal process }\end{array}$ & $\begin{array}{c}\text { Legal } \\
\text { recognition }\end{array}$ & $\begin{array}{c}\text { Post legal } \\
\text { recognition }\end{array}$ \\
\hline Mollo & & & & \\
\hline Baranusa & & & & \\
\hline Wologai & & & & \\
\hline
\end{tabular}

Figure 2 The stages of achievement of adat recognition in study area.

Baranusa customary community (1) Overview of customary community The Baranusa customary community is the heir of the small kingdoms that occupied the Pantar Island region. The current Baranusa king is the $16^{\text {th }}$ generation. The crowning has been done hereditary from the first generation to the $16^{\text {th }}$ generation. However, the $12^{\text {th }}$ to $15^{\text {th }}$ kings had to get approval from the Dutch government controlling the Lesser Sunda region. In exchange for accepting the Dutch government's sovereignty, the Baranusa Kingdom received the "obedience letter" from the Dutch government in 1896, which granted honorary title (Koninlijk) and agrarian rights to the king. It resulted in the leaders of the kingdom became subordinate to the Dutch colonial government. In contrast, many small local kingdoms in the mountainous area did not agree with the customary territorial claims based on the Baranusa custom. They have had their customs and have claimed that their ones are not a part of the customary law of the Baranusa. After Indonesia's independence, the Baranusa Kingdom transformed into a village in West Pantar District, where the sub-district capital is located. 
Table 2 The forest/land management of customary community and their response towards CCD

\begin{tabular}{|c|c|c|}
\hline $\begin{array}{l}\text { Customary } \\
\text { community }\end{array}$ & Before CCD & After CCD \\
\hline Mollo & $\begin{array}{l}\text { - Access the state forest for livelihood } \\
\text { - Collaborate with empowering NGO }\end{array}$ & $\begin{array}{l}\text { - Access the state forest for livelihood } \\
\text { - Not proposing a customary forest as long } \\
\text { as the access can be granted }\end{array}$ \\
\hline Baranusa & $\begin{array}{l}\text { - Manage the sea for a livelihood } \\
\text { - Collaborate with empowering NGO } \\
\text { and Adat revivalism NGO }\end{array}$ & $\begin{array}{l}\text { - Imply the traditional "grace period } \\
\text { system." } \\
\text { - Propose the customary area to BRWA } \\
\text { and actively revive customs and } \\
\text { institutions }\end{array}$ \\
\hline Nua Wologai & $\begin{array}{l}\text { - Maintain the sacred forest } \\
\text { - Collaborate with Adat revivalism } \\
\text { NGO }\end{array}$ & $\begin{array}{l}\text { - Maintain the sacred forest } \\
\text { - Propose the customary area to BRWA } \\
\text { and actively revive customs and } \\
\text { institutions to many stakeholders }\end{array}$ \\
\hline
\end{tabular}

Today, they are still keeping their customary norms, such as the marriage system, culture ceremony for farming, and local wisdom in managing natural resources. One of them is a traditional management system for the coastal and marine areas called Hading Mulung and Hoba Mulung. The fishers are allowed to use only environmentally friendly fishing gear in the Hoba Mulung area. Meanwhile, all types of fishing equipment, including traditional fishing tools, are prohibited for a certain period in the Hading Mulung area. Plaimo (2020) mentions that the Mulung activities positively affect fishers' income because Mulung provides time for marine biota to recover the sustainable conditions so that they can catch fish continuously. These traditional fishing systems and marriage systems make the Baranusa customary community unique.

(2) Impacts of the CCD Land tenure analysis The CCD gave the Baranusa people the spirit to revive their customary community. They initiated the revival activities in 2015 and formed an adat council consisting of representatives of customary leaders from several villages. Then, the $16^{\text {th }}$ king registered 5,000 ha of coastal and marine areas as their customary area on 2 June 2017. Many Baranusa people have made a living by running agriculture and fisheries for generations. However, they were facing the overfishing problem. Therefore, their primary purpose of the registration was to preserve the coral reef and coastal ecosystems for their livelihoods. Meanwhile, WWF International-Lesser Sunda Projects supported this initiative to conserve mainly the "triangle" coastal area between Lapang Island and Batang Island (WWF Indonesia, 2019).

Preparation on entering legal process After a series of informal meetings, they held the formal meeting on 27 November 2017. At this meeting, they formed the Baranusa customary institution consisting of the advisory board (King of Baranusa and West Pantar sub-district head), chairmansecretary, treasurer, and the representatives of five tribal groups (Uma Kakang, Waliweka, Sandiata, Maloku, and Illu). Therefore, the CCD was an opportunity for Baranusa customary community to establish the legal rule on protecting their "claiming" customary coastal area. On the other hand, the king of Baranusa said that they proposed ocean territory instead of land territory as their customary territory to avoid frequent disputes among customary communities. A neighboring clan of the Baranusa customary community also testified that they could not accept if the Baranusa claimed all the Pantar Island under the same cultural family as Baranusa.

Mollo customary community (1) Overview of customary community Before Indonesia's independence, there were three autonomous regions (swapraja) in the Timor Tengah Selatan district: Mollo, Amanutun, and Amanuban (Parera, 1994). The three swapraja were a part of the Atoni ethnic group that was the largest ethnic group occupied the western part of Timor island. The Mollo customary community was one of the three swapraja. After Indonesia's independence, the three swapraja transformed into 32 sub-districts in the Timor Tengah Selatan district. Nowadays, the Mollo customary community's people are domiciling in four subdistricts in Timor Tengah Selatan district (BPS Kabupaten Timor Tengah Selatan, 2017). Sonbai Fam is one of the most prominent families of the Mollo people, and the current throne is the heir of the Sonbai family. They have an evident pedigree and still adheres to their customs.

The Mollo people are known as the people with dryland farming and raising livestock. Besides, they are also famous as the people who have the concept of the triangle of life consisting of nature, humans, and livestock (mansian muit nasi moni nabuan in their language), which means humans, forests, and livestock are an inseparable part and have interdependent relations. They have maintained their customs for generations, and one of them is the customary land system called suf. In general, the suf is described as ulayat land (customary land) in a state forest area. They collected NTFPs in the suf and inherited the suf in a family group for generations. There is no official data on the number of suf within the conservation area or protected area of the state forest in the Timor Tengah Selatan district. They were harvesting honey in the nature reserves or protected areas of the state forests in Kupang district and Timor Tengah Selatan district. (Budiman et al., 2020) also found the Mollo people harvesting honey in the strict conservation area of the Gunung Mutis Nature Reserveng Natural Resources and Ecosystem Conservation. 
(2) Impact of the CCD Land tenure analysis Unlike the Baranusa customary community, the Mollo customary communities have never had the desire to change the status of suf from the state forest to customary forests. They emphasized the importance of access to suf that they had inherited for generations. Therefore, the state has not recognized their suf, but it does not matter for them as long as their customary access rights for non-timber forest products in suf are secured.

Preparation on entering legal process The Ministerial Regulation Number $17 / 2020$ prescribes that regional regulations must stipulate the customary law community's regulations expressly. To promote legislation on customary forests of Mollo customary communities, the Forest Management Unit (FMU) officer suggested that their customary leaders often consult with district legislative members. The communication between the customary leaders and the district legislative members or local authorities is essential to make regional regulation on customary forests. Van der Muur (2018) also reported a case of South Sulawesi that closeness to bureaucrats was a vital factor for accelerating recognition of customary territories.

Nua Wologai Tana Sigaria customary community (1) Overview of customary community Before 1932 the land was owned communally by the Siga Ria family. The first territorialization happened after the Dutch colonial government reached the East Nusa Tenggara. The Dutch colonial government gazetted a protected forest boundary outside the arable lands of the Wologai people.

After Indonesia's independence, the state forestry agency declared a protected forest boundary intersecting the cultivated area of the Wologai people in 1984. The Wologai people testified that some parts of the protected forests were their customary forests for traditional ceremonies. Besides, they could previously use wood from the forests for building traditional houses. However, the state forest agency has not allowed those activities. Currently, those forests are under the management of Ende FMU as protected forests. The Wologai people do not have legal access to their customary forests in the protected forest.

(2) Impact of the CCD Land tenure analysis In a legal process, the community was assisted by a local NGO, AMAN Nusabunga, an AMAN network for the Bali and Nusa Tenggara area. The process was initiated in 2015 when AMAN Nusabunga started collecting data on the characteristics of the Nua Wologai customary community. The collected data were the identity of the community (e.g., name of the community and administrative location), identification of the customary territory including the border of the area, demography, a brief history of the customary community, communal land rights and territorial management, customary institution, customary laws, and its biodiversity.

Preparation on entering legal process AMAN Nusabunga carried out a participatory mapping with the adat leaders and the indigenous youths regarding their customary area. The mapping process in 2015 figured out some land management that should be further proposed as a customary community area to BRWA. The customary community areas consist of four areas: bodhe, ngebo, uma, and nua. The bodhe is the traditional forest area utilized for springs, sacred sites, and traditional ceremonies. The Ngebo is a communal forest area that can be used for community gardens and cultivations. The uma is an arable area in the shape of gardens, fields, and former gardens or fields covering by food crops such as mountain rice and commodity crops. The nua is a settlement area used as residences of people (BRWA, 2017).

The role of local NGOs is vital in the process of legal recognition. A chief of AMAN Nusabunga was a member of the Regional People's Representative Assembly (Dewan Perwakilan Rakyat Daerah) in two periods (2009-2014 and 2014-2019) and played a crucial role in lobbying the fellow of the Ende districts legislative members. As a council member, he also educated customary communities in Ende Regency, and one of them is NuaWologai customary community. Low awareness of the legislature members to the urgency of the legal existence of customary society was the biggest challenge in the process. At least five to six times comprehensive meetings with community members were necessary until they registered the customary community to the BRWA on 2 December 2015.

Eventually, their struggle was a success on 15 August 2017. The regional government enacted the Ende District Regulation No.2 of the Implementation of Recognition and Protection of Customary Law Communities. The regulation defines several rights and obligations of the customary communities. The stipulated rights are (1) land, customary territories, and natural resources, (2) development, (3) spirituality and culture, (4) environment, and (5) implementation of the customary law and court. Meanwhile, the regulation obliges the customary communities to (1) participate in mutually agreed-upon development processes, (2) keep the cultural values of Indonesia maintaining tolerance between indigenous and tribal peoples, (3) comply with the provisions of laws and regulations, (4) conserve the environment in their customary territories sustainably, (5) be subject to the unique habits, spirituality, traditions, values, and customary courts that apply in the customary law community, and (6) cooperate in the process of identification and verification of indigenous and tribal peoples.

The struggle for recognition on adat also got positive support from the regent of in Ende district. The relation between the regent and the AMAN Nusabunga was excellent, and their communication was also very well. Such a formal relationship between representatives of adat community was essential to develop the understanding of the stakeholders. Van der Muur (2018) argues that the indigenous group who have a strong connection with the local state actor will get a better advantage. However, unfortunately, the legal process in the Ende district is hampered after the death of the regent in May 2019.

Barriers to the development of customarty forest in ENT Province The MoEF Regulation Number 17/2020 mandates that the community must be acknowledged as a customary law community (Masyarakat Hukum Adat/MHA) before proposing their forest area as a customary forest. Previously, to be obtained the position of MHA, the customary 
community must fulfill some process stated in Ministry of Internal Affairs Regulation Number 52 in 2014 about Guidelines for the Recognition and Protection of Indigenous Communities. There are two steps of recognition (Figure 3). According to the interview with customary leaders and the ENT provincial forestry officer, we found two main obstacles in the development of the customary forests in the ENT Province: (1) the complicated political process in the district government and (2) the competition of CF program with other central government programs.

(1) The complicated political process in the district government The formalization becomes one of the enforceable factors for customary right recognition (Simarmata, 2019). In a fast and structured manner, the central government made various efforts to follow up the CCD. On the other hand, as shown in Figure 3, the district governments have a vital role in recognizing indigenous communities. The steps include 1) formation of committees, 2) identification, 3) verification and validation, and 4) appointment of indigenous communities.

Until March 2021, among the 22 districts in the ENT Province, only three districts (i.e., Ende District, Alor District, and Manggarai Timur District) have local regulations regarding the customary community. Meanwhile, there is no district regulation explicitly related to the recognition, protection, or empowerment of indigenous communities. Elites, traditional elders, council members, and bureaucrats in charge of indigenous peoples and forestry continue discussing these issues. Although the traditional culture is robust in the ENT Province, they have different perceptions about the urgency of establishing customary forests in the three study sites.

The case of Ende District, the first district that imposes regulation on customary community protection and acknowledgment, showed that it took at least five years of struggle to establish the regulation. The initiator came from the legislative member, who is also one of the influential people in the district. However, our interview revealed that building awareness of the urgency of recognizing indigenous peoples among legislators required time and a long process.

In that sense, funding plays an essential role in the customary community establishment facilitation. The trial process in the legislature and the facilitation of many stakeholder meetings required an adequate budget. Based on the MoEF Regulation Number P.17/2020, the proposals of the customary community must come from the customary community self-budget. Therefore, assistance from NGOs and regional revenue and expenditure budgets (Anggaran Pendapatan dan Belanja Daerah/APBD) are necessary because the process is very long and involves many parties. However, it seems that financing for the facilitation and initiation of the establishment of customary forests has not become a top priority of district governments. It is evident from the relatively small budget for assistants in the three districts for facilitating the customary community establishment.

(2) The competition with other government programs Currently, the agrarian reform (Tanah Objek Reformasi Agraria/TORA) and the social forestry scheme are the two mainstream programs of the central government in the forestry sector. Those programs offer rights in the state forest area to be managed or owned by communities or individuals. These two programs aim to solve the land dispute problem, which involves the community around the forest area, including customary community and indigenous people. As in another province, for instance in West Sumatera (Asmin et al., 2019), the popular schemes are hutan desa (village forest), hutan kemasyarakatan (community forest), and hutan tanaman rakyat (community plantation forest).

According to the ENT provincial officer, particularly in Flores Island, customary communities competed with the communities pursuing social forestry licenses. The They were also actively proposing and negotiating to get the land utilization rights through the TORA scheme. Those communities desired to get their prestige by obtaining a TORA certificate and assistance for social forestry activities. TORA was the choice for many communities in the ENT Province because it was related to individual land ownership rights. The social forestry program also provided a lot of facilitation and funding in implementing activities in the field.

Policy challenges of the CCD The enactment of the new local government law (Law Number 23/2014), replaced with Law Number 32/2004, has recentralized several authorities from the district level to the provincial level, such as natural resources extraction, mining, and forestry. As one of its impacts, the district forestry service was dissolved and replaced with the provincial FMU in the ENT Province. The FMUs have focused mainly on forest protection and social forestry programs as an extension of the provincial government. Therefore, the customary forest issues are still not a priority in the FMU. According to a provincial forestry officer, they did not have a specialized unit to handle the customary forest issue. He explained that a sub-unit addressed customary forest issues while dealing with the social forestry program, and their main activities were mainly data collection on the customary forests.

The Ministerial Regulation Number 32/2015 about the Right Forest, updated by Ministerial Regulation Number $17 / 2020$, gives the mandate to the district government as the focal point to deal with the legislation process of customary forests. However, as of the end of 2020, there was no district regulating the customary community except for three districts: Ende District (District Regulation Number 2/2017), East Manggarai district (District Regulation Number 1/2018), and Alor District (District Regulation Number 4/2018). The scarcity of regional regulations regarding customary law is still the leading cause to hinder the legislation process of customary forests in the ENT Province.

According to our interview, there were some reasons. Firstly, there was no "umbrella" regulation protecting indigenous peoples in the ENT Province. Secondly, information access on "how to" apply for the customary forests was limited. Lastly, as the case of the Mollo customary community showed, some customary communities did not need to change the status of their forest as long as the local government recognized their existence sufficiently. In other words, any forest status is acceptable for 
them as long as the local government secures their access to the forests for their livelihood and cultural activities. Tyson (2010) affirms that "recognition" is a crucial aspect sought by all actors in all parties. He also argues that only the state can secure recognition, apply arrangements, and establish an ethnic group and a traditional community. Therefore, the recognition of customary communities and their forests is a significant policy challenge in Indonesian forestry to unravel the tangled tenurial conflicts in forest areas that continues to this day.

Another significant policy challenge of the CCD is overlapping the claim area between customary communities. It can cause horizontal conflicts and negatively impact customary communities if this policy challenge is not resolved appropriately. The ENT Province is characterized by very tolerant and has fewer problems related to tribal, religious, and racial (Suku Agama Ras dan Antargolongan: SARA) compared to other provinces. However, recently, it is rising a concern that land conflict over customary forests will damage tribal, religious, and racial relations. We clarified that the Baranusa customary community proposed ocean territory instead of land territory as their customary territory to avoid frequent disputes among customary communities. The recognition for the land right is essential in customary community existence in the forestry sectors of Indonesia.

In this context, Safitri (2017) proposed establishing the Indigenous People Act to protect indigenous peoples' rights in Indonesia. She showed three critical factors causing the delay in recognizing the customary people's rights by the government. The First one is that there has not been a consistent legal umbrella that nationally recognizes indigenous people and customary communities. The second one is that there is still a misunderstanding among foresters that forest areas should be state forests, and its management should exclude people. Thirdly, there are still political and economic interests of local governments that want to allocate the lands for large-scale investments rather than customary forests.

\section{Conclusion}

Our findings clearly showed three different responses of the customary communities towards CCD in the ENT Province. The Nua Wologai customary community proposed the customary forest as their rights. The Baranusa customary community tried to revive the adat and traditions to maintain the ecosystem sustainability where they depend on their livelihood. The Mollo customary community did not desire to obtain the legal status of their customary forests (suf) as long as their activities in the forest are guaranteed. Besides, we clarified the possibility of new land conflict among customary communities. Some customary forests claimed by a customary community are overlapping with the claims by other customary communities. This situation is closely related to the history of the formation of the Republic of Indonesia. Therefore, careful consideration for land history and different perceptions on customary forests among customary communities are crucial in the verification process of customary forests.

\section{Recommendation}

Our study in the ENT Province described the diverse perception of customary forests between customary communities. Indonesia is an archipelago country composed of countless small islands and various ethnic groups with unique livelihoods. Reportedly, there are 55 ethnic groups in the only ENT Province alone. Therefore, we recommend that the national and provincial policymaking process should take into account each locality around customary forests. The role of the regional government, which connects central and local governments, is vital to facilitate the customary forest initiative.

\section{Acknowledgment}

This work was supported by JSPS KAKENHI Grant Numbers JP15H05122 and JP17K15340. Also, we thank field research teams of Kupang Forestry Research and Development Institute researchers as well as customary community leaders who helped our field research.

\section{References}

Almeida, F. (2014). Legal recognition of forest rights of indigenous peoples and local communities. In M. Köhl \& L. Pancel (Eds.), Tropical forestry handbook (pp. 1-28). Springer Berlin Heidelberg. https://doi.org/10.1007/9783-642-41554-8 292-1

Arizona, Y., Wicaksono, M. T., \& Vel, J. (2019). The role of indigeneity NGOs in the legal recognition of adat communities and customary forests in Indonesia. The Asia Pacific Journal of Anthropology, 20(5), 487-506. https://doi.org/10.1080/14442213.2019.1670241

Asmin, F. (2016). Reforma agraria bidang kehutanan: Sebuah tinjauan politik simbolik. Retrived from https://www.researchgate.net/publication/303328634

Asmin, F., Darusman, D., Ichwandi, I., \& Suharjito, D. (2019). Mainstreaming community-based forest management in west sumatra: Social forestry arguments, support, and implementation. Forest and Society, 3(1), 77-96. https://doi.org/10.24259/fs.v3i1.4047

Bakker, L., \& Moniaga, S. (2010). The space between: Land claims and the law in Indonesia. Asian Journal of Social Science, 38(2), 187-203. https://doi.org/10.1163/ $156853110 X 490890$

Bedner, A., \& Arizona, Y. (2019). Adat in Indonesian land law: A promise for the future or a dead end? The Asia Pacific Journal of Anthropology, 20(5), 416-434. https://doi.org/10.1080/14442213.2019.1670246

[BPS] Badan Pusat Statistik Kabupaten Timor Tengah Selatan. (2017). Kabupaten Timor Tengah Selatan Dalam Angka. Kupang: Badan Pusat Statistik Kabupaten Kupang. Kupang.

[BRWA] Badan Registrasi Wilayah Adat. (2017). Wilayah 
adat Nua Wologai. Retrieved from: https://www.brwa.or.id/wa/view/XzYtblpPR31DUjg

Budiman, I., Fujiwara, T., Sato, N., \& Pamungkas, D. (2020). Another law in Indonesia: Customary land tenure system coexisting with state order in Mutis Forest. Jurnal Manajemen Hutan Tropika, 26(3), 244-253. https://doi.org/10.7226/jtfm.26.3.244

Camacho, L. D., Combalicer, M. S., Yeo-Chang, Y., Combalicer, E. A., Carandang, A. P., Camacho, S. C., ..., \& Rebugio, L. L. (2012). Traditional forest conservation knowledge/technologies in the Cordillera, Northern Philippines. Forest Policy and Economics, 22, 3-8. https://doi.org/10.1016/j.forpol.2010.06.001

Creswell, J. W., \& Creswell, J. D. (2018). Research design: Qualitative, quantitative, and mixed methods approaches (5th ed.). California: SAGE.

[Ditjen PSKL KLHK] Direktorat Jenderal Perhutanan Sosial dan Kemitraan Lingkungan Kementerian Kehutanan dan Lingkungan. (2019). Profil peta hutan adat dan wilayah indikatif hutan adat fase I. Retrieved from: http://dlhk.acehprov.go.id/2019/05/klhklaunching-peta-hutan-adat-dan-wilayah-indikatifhutan-adat-fase-i/

Dunn, W. N. (1981). Public policy analysis: An introduction. New Jersey: Prentice-Hall.

Grimes, C. E., Therik, T., Grimes, B. D., \& Jacob, M. (1997). A guide to the people and languages of Nusa Tenggara. Kupang: Artha Wacana Press

Guest, P. (2017). Indonesia's indigenous voices turn on Widodo. Nikkei Asia Review. Retrieved from: https://asia.nikkei.com/Economy/Indonesia-sindigenous-voices-turn-on-Widodo

Hidayat, H., Yogaswara, H., Herawati, T., Blazey, P., Wyatt, S., \& Howitt, R. (2018). Forests, law and customary rights in Indonesia: Implications of a decision of the Indonesian Constitutional Court in 2012. Asia Pacific Viewpoint, 59(3), 293-308. https://doi.org/10.1111/apv. 12207

Iswandono, E., Zuhud, E. A. M., Hikmat, A., \& Kosmaryandi, N. (2015). Integrating local culture into forest conservation: A case study of The Manggarai Tribe in Ruteng Mountains, Indonesia. Jurnal Manajemen Hutan Tropika, 21(2), 55-64. https://doi.org/ 10.7226/jtfm.21.2.55

Iswandono, E., Zuhud, E. A. M., Hikmat, A., \& Kosmaryandi, N. (2016). Traditional land practice and forest conservation: Case study of The Manggarai Tribe in Ruteng Mountains, Indonesia. Komunitas: International Journal of Indonesian Society and Culture, 8(2), 256. https://doi.org/10.15294/komunitas. v8i2.4945
Indonesian Geospatial Information Agency (2018). Peta RBI format shp. Retrived from: https://tanahair. indonesia.go.id/portal-web

Jampolsky, J. A., \& Carpenter, K. A. (2015). Indigenous rights. In International encyclopedia of the social \& behavioral sciences: Second edition. Elsevier. https://doi.org/10.1016/B978-0-08-097086-8.86120-6

Kilkoda, M. (2015). Pulau-pulau kecil dan persoalan ruang hidup di Maluku Utara. Buletin Intip Hutan. Retrieved from: http://fwi.or.id/publikasi/pulau-pulau-kecil-danpersoalan-ruang-hidup-di-maluku-utara/

Krishna, V. V., Kubitza, C., Pascual, U., \& Qaim, M. (2017). Land markets, property rights, and deforestation: insights from Indonesia. World Development, 99, 335-349. https://doi.org/10.1016/j.worlddev.2017.05.018

Kriswoyo, K., Pello, J., \& Kaho, L. M. R. (2019). Peranan tiga pilar dalam penyelesaian konflik tenurial di Taman Wisata Alam Ruteng, Flores, Nusa Tenggara Timur. Bumi Lestari Journal of Environment, 19(1), 36-48. https://doi.org/10.24843/blje.2019.v19.i01.p05

Lund, C., \& Rachman, N. F. (2018). Indirect recognition. Frontiers and territorialization around Mount HalimunSalak National Park, Indonesia. World Development, 101(40), 417-428. https://doi.org/10.1016/j.worlddev. 2017.04 .003

[MoEF] Ministry of Environment and Forestry. (2020). Ministry Regulation Number 17/2020. Retrieved from: http://jdih.menlhk.co.id/uploads/files/P_17_2020_HUT AN_ADAT_dan_HUTAN_HAK_menlhk_0925202009 2916.pdf

[MoHA] Ministry of Home Affair. (2014). Ministry Regulation Number 52/2014. Retrieved from: https://www.aman.or.id/wp-content/uploads/2014/08/ Permendagri-Nomor-52-Tahun-2014.pdf

Monk, K. A., De Fretes, Y., \& Reksodiharjo-Lilley, G. (1997). The ecology of Nusa Tenggara and Maluku. Singapore: Periplus Editions.

Myers, R., Intarini, D., Sirait, M. T., \& Maryudi, A. (2017). Claiming the forest: Inclusions and exclusions under Indonesia's 'new' forest policies on customary forests. Land Use Policy, 66, 205-213. https://doi.org/10.1016/ j.landusepol.2017.04.039

Parera, A. D. M. (1994). Sejarah pemerintahan raja-raja Timor: Suatu kajian atas peta politik pemerintahan kerajaan-kerajaan di Timor sebelum kemerdekaan Republik Indonesia. (G. Neonbasu (Ed.). Jakarta: Pustaka Sinar Harapan.

Peluso, N. L., \& Vandergeest, P. (2001). Genealogies of the political forest and customary rights in Indonesia, Malaysia, and Thailand. The Journal of Asian Studies, 60(3), 761-812. https://doi.org/10.2307/2700109 
Peluso, N. L., Afiff, S., \& Rachman, N. F. (2008). Claiming the grounds for reform: Agrarian and environmental movements in Indonesia. Journal of Agrarian Change, 8(2-3), 377-407. https://doi.org/10.1111/j.1471-0366. 2008.00174.x

Plaimo, P. E. (2020). Identifikasi faktor penunjang keberlanjutan tradisi budaya mulung. Retrived from https://doi.org/10.31227/osf.io/bpfsh.

Powell, J. (Ed.), Hartanto, H., Short, C. (Ed.), Rangan, H., Thorburn, C. C., \& Kull, C. A. (2008). Strategic Engagement and Dynamic Adaptation: Customary Forest Management in Kerinci Central Sumatra Indonesia. 1-30. Biennial Conference of the International Association for the Study of Commons, http//dic.dlib.indiana.edu/archive/00003827/(website hosted at Champagne-Urbana Indiana).

Roth, D. (2011). The subak in diaspora: Balinese farmers and the subak in South Sulawesi. Human Ecology, 39(1), 55-68. https://doi.org/10.1007/s10745-010-9374-7

Safitri, M. (2017). Dividing the land: Legal gaps in the recognition of customary land in Indonesian forest areas. Kasarinlan: Philippine Journal of Third World Studies, 30(2,1), 31-48.

Simarmata, R. (2019). The enforceability of formalised customary land rights in Indonesia. Australian Journal of Asian Law, 19(2), 1-15

Sirait, M., Fay, C., \& Kusworo, A. (2000). Bagaimana hakhak masyarakat hukum adat dalam mengelola sumber daya alam diatur. Southeast Asia Policy Research Working Paper, 24, 1-32.

Siscawati, M., Banjade, M. R., Liswanti, N., Herawati, T., Mwangi, E., Wulandari, C., ... \& Silaya, T. (2017). Overview of forest tenure reforms in Indonesia (Working Paper 223). Center for International Forestry Research. https://doi.org/10.17528/cifor/006402

Soemardjan, S. (1962). Land reform in Indonesia. Asian Survey, 1(12), 23-30. https://doi.org/10.2307/3023456

Sopian, N. L. (2015). Informal dispute resolution based on adat law: A case study of land dispute in Flores, East Nusa Tenggara, Indonesia. Indonesia Law Review, 5(2), 106. https://doi.org/10.15742/ilrev.v5n2.157
Suartika, G. A. M. (2007). Territoriality and the market system-adat land v.s. state regulations on land matters in Bali. Habitat International, 31(2), 167-176. https://doi.org/10.1016/j.habitatint.2006.11.001

Subarudi. (2014). Kebijakan pengelolaan hutan adat pasca putusan Mahkamah Konstitusi No. 35/Puu-X/2012: Suatu tinjauan kritis. Analisis Kebijakan Kehutanan, 11(3), 207-224.

Suryadi, S. (2013, July 2). Eksistensi hutan adat paska putusan MK 35 [Conference Presentation]. Seminar Pembangunan Kehutanan Berkelanjutan dalam Perspektif Tata Ruang. Balai Litbang Kehutanan Kupang.

Tyson, A. D. (2010). Decentralization and adat revivalism in Indonesia: The politics of becoming indigenous (1st ed.). Routledge. https://doi.org/10.4324/9780203849903

Upton, S. (2017). Demography of Indonesia's ethnicity. Asian Studies Review, 41(1), 164-165. https://doi.org/ $10.1080 / 10357823.2016 .1202173$

Van der Muur, W. (2018). Forest conflicts and the informal nature of realizing indigenous land rights in Indonesia. Citizenship Studies, 22(2), 160-174. https://doi.org/ 10.1080/13621025.2018.1445495

Vandergeest, P., \& Peluso, N. L. (1995). Territorialization and state power in Thailand. Theory and Society, 24(3), 385-426. Retrieved from http://www.jstor.org/stable/ 658074

Vandergeest, P., \& Peluso, N. L. (2015). Political forests. In R. L. Bryant (Ed.), The international handbook of political ecology (pp.162175). Cheltenham: Edward Elgar Publishing. Retrieved from https://doi.org/ $10.4337 / 9780857936172.00020$

Wibowo, L. R., Murdianti, C. W., Race, D., \& Murdiningrum, Y. A. (2014). Forest policy and legal pluralism: A case study in Luwu District, Indonesia. Indonesia Law Review, 2(1), 1. https://doi.org/10.15742/ ilrev.v2n1.9

[WWF] World Wildlife Fund Indonesia. (2019). Impact stories 2018. Jakarta: WWF Indonesia. Retrieved from: https://www.wwf.id/publikasi/wwf-indonesia-impactstories-2018 